\title{
PENERAPAN PENDIDIKAN KARAKTER DALAM PEMBELAJARAN DI SD NEGERI DOMBO 1
}

\author{
REJO \\ SD Negeri Dombo 1, Kecamatan Sayung, Kabupaten Demak \\ Email: rejo1166@gmail.com
}

\begin{abstract}
ABSTRAK
Penelitian ini bertujuan untuk mendeskripsikan implementasi pendidikan karakter dalam pembelajaran serta mengetahui faktor pendukung dan penghambat dalam implementasi pendidikan karakter dalam pembelajaran di SD Negeri Dombo 1 Syung, Demak. Penelitian ini menggunakan pendekatan kualitatif dengan studi kasus tunggal. Data dikumpulkan dengan menggunakan wawancara mendalam, observasi, dokumentasi, dan data dianalisis secara kualitatif deskriptif. Hasil penelitian menunjukkan, implementasi pendidikan karakter di sekolah tersebut dilaksanakan secara terintegrasi dalam semua mata pelajaran, kegiatan ekstrakurikuler, dan kegiatan pembiasaan. Hasil penelitian ini diharapkan dapat bermanfaat bagi para pendidik dan tenaga kependidikan untuk melakukan inovasi dalam rangka meningkatkan mutu pembelajaran yang terkait dengan pembentukan karakter siswa.
\end{abstract}

Kata kunci: sekolah dasar Islam, pendidikan karakter, pembelajaran

\section{ABSTRACT}

The purpose of this research is to describes about the implementation of character education in learning and to know the supporting factors and restricting factor in the implementation of character education in learning in SD Negeri Dombo 1 Sayung, Demak. This research employed a qualitative approach with a single case study. Data were collected by using indepth interviews, observation, documentation, and finally data were analized by qualitative descriptive. The results showed that the implementation of character education in schools is carried out in an integrated manner in all subjects, in extracurricular activities, and the activities of habituation. The results of this study are expected to be useful for educators and education personnel to make innovations in order to improve the quality of learning associated with the formation of students character.

Key Words: Islamic primary school, character education, learning

\section{PENDAHULUAN}

Sesuai Undang-Undang Republik Indonesia Nomor 20 tahun 2003 tentang Sistem Pendidikan Nasional menjelaskan bahwa pengertian "pendidikan adalah suatu usaha sadar dan terencana untuk mewujudkan suasana belajar dan proses pembelajaran agar peserta didik secara aktif mengembangkan potensi dirinya untuk memiliki kekuatan spiritual keagamaan, pengendalian diri, kepribadian, kecerdasan, akhlak mulia, serta keterampilan yang dibutuhkan oleh dirinya, masyarakat, bangsa dan negara". Pendidikan juga sebagai pembentukan karakter peserta didik untuk menjadi pemimpin yang memiliki fitrah, roh dan jasmani, kemauan yang bebas, dan akal yang sehat agar mereka dapat membangun potensi dirinya sehingga menjadi seorang pemimpin sejati,

Pendidikan nasional berfungsi mengembangkan kemampuan dan membentuk watak serta peradaban bangsa yang bermartabat dalam rangka mencerdaskan kehidupan bangsa, bertujuan untuk berkembangnya potensi peserta didik agar menjadi manusia yang beriman dan bertakwa kepada Tuhan Yang Maha Esaberakhlak mulia, sehat, berilmu, cakap, kreatif, mandiri, dan menjadi warga negara yang demokratis serta bertanggung jawab.

Sesuai perihal tersebut di atas, secara formal berbagai upaya untuk menyiapkan kondisi, sarana dan prasarana, kegiatan, pendidikan, dan kurikulum yang mengarah kepada pembentukan watak dan budi pekerti serta karakter generasi muda bangsa harus memiliki landasan hukum yang kuat. Sejak tahun 2010, pemerintah Indonesia telah mencanangkan 
gerakan "Pendidikan Budaya dan Karakter Bangsa". Gerakan pemerintah tersebut merupakan suatu usaha dalam mewujudkan tujuan pendidikan nasional di atas. Supaya dapat mencapai hasil yang maksimal dari gerakan pemerintah tersebut, maka perlu penerapan secara berkelanjutan dan sistematis. Secara terminologi, makna karakter yang dikemukakan Lickona (2012:34) bahwa karakter adalah "a reliable inner disposition to respond to situations in a morally good way". Selanjutnya Lickona (2012:34) menambahkan, "character so conceived has three interrelated parts: moral knowing, moral feeling, and behavior”. Dari pendapat serta pernyataan di atas bahwa karkater itu meliputi pengetahuan tentang kebaikan dan akhirnya benar-benar melakukan kebaikan. Dengan kata lain, karakter mengacu kepada serangkaian pengetahuan, sikap, motivasi, perilaku, dan keterampilan. Dari beberapa pengertian pendidikan dan karakter di atas maka dapat disimpulkan bahwa pendidikan karakter adalah usaha dengan sadar yang dilakukan oleh pendidik atau guru kepada peserta didiknya untuk membentuk kepribadian peserta didik yang mengajarkan dan membentuk moral, etika, sikap, motivasi, perilaku, keterampilan, dan rasa berbudaya yang baik serta berakhlak mulia sehingga menumbuhkan kemampuan peserta didik untuk mengambil keputusan baik maupun buruk serta mewujudkan kebaikan itu dalam kehidupan sehari-hari.

Sekolah Dasar Negeri Dombo 1 Kecamatan Sayung Kabupaten Demak Provinsi Jawa Tengah merupakan lembaga pendidikan dasar yang komitmen dalam menanamkan karakter pada peserta didiknya sehingga benar-benar mampu membangun karakter (character building) kepada peserta didiknya. Penerapan dalam pendalaman dan pengayaan nilai- nilai budaya dan agama dalam kehidupan sehari-hari disajikan melalui (1) pendekatan terintegrasi dalam semua mata pelajaran; (2) pengembangan budaya satuan pendidikan; (3) pelaksanaan kegiatan kokurikuler dan ekstrakurikuler; (4) pembiasaan perilaku dalam kehidupan di lingkungan Sekolah. Kegiatan-kegiatan tersebut di atas merupakan suatu bentuk usaha yang dilakukan di Sekolah Dasar Negeri Dombo 1 untuk menanamkan karakter kepada peserta didiknya. Kegiatan pembiasaan yang terus-menerus dilakukan akan menjadi karakter yang melekat pada diri peserta didik. Penyelenggara pendidikan di Sekolah tersebut yang terdiri dari tenaga pendidik dan tenaga kependidikan memiliki tanggung jawab untuk menerapkan gagasan dan konsep pendidikan dalam membentuk karakter peserta didik di sekolah tersebut. Hal ini memerlukan suatu perjuangan yang ulet, komitmen, kerja keras, dan konsisten agar dapat terealisasi dengan baik. Berdasarkan uraian tersebut, maka dipandang perlu untuk diadakan penelitian dengan memfokuskan kepada penerapan pendidikan karakter dalam pembelajaran Sekolah Dasar Negeri Dombo 1 Kecamatan Sayung Kabupaten Demak. Penelitian ini berusaha menggali penerapan pendidikan karkater dalam pembelajaran, dan untuk mengungkapkan berbagai faktor pendukung dan penghambat dalam penerapaan pendidikan karakter dalam pembelajaran tersebut sehingga dapat dijadikan masukan ataupun saran bagi sekolah tersebut untuk mengembangkan potensi yang dimiliki dalam pengembangan kurikulum dan pembelajaran di sekolah tersebuttersebut.

\section{METODE PENELITIAN}

Penelitian ini menggunakan pendekatan kualitatif deskriptif. Pendekatan kualitatif bertujuan untuk memahami lebih mendalam bagaimana Implementasi pendidikan karakter dalam pembelajaran diterapkan pada sekolah tersebut. Penelitian ini lebih menekankan pada pengungkapan makna dan proses dengan latar belakang alami (natural setting) sebagai sumber data langsung. penelitian ini dirancang dengan menggunakan desain studi kasus karena terpusat hanya pada satu obyek penelitian dan menekankan pada pengungkapan yang mendalam sesuai dengan focus penelitian. Sesuai dengan pendapat Bogdan dan Biklen (1998) menjelaskan bahwa rancangan studi kasus merupakan salah satu bentuk rancangan kualitatif yang lebih menekankan pada pengungkapan secara terperinci dan mendalam terhadap suatu obyek, peristiwa, atau kejadian tertentu.

Studi kasus (case study), merupakan suatu penelitian yang diarahkan untuk mengumpulkan data, mengambil makna, dan memperoleh pemahaman dari suatu kasus. Pada 
studi kasus ini bersifat terpancang (single case design) artinya peneliti memusatkan perhatiannya pada kasus yang telah ditetapkan yaitu penerapan pendidikan karakter dalam pembelajaran yang terjadi di Sekolah Dasar Negeri Dombo 1 Kecamatan Sayung kabupaten Demak. Selain itu penelitian ini juga berdasarkan pandangan, pemikiran, tindakan berbagai pihak yang terlibat dalam pelaksanaan pendidikan karakter dalam pembelajaran, dan faktor yang mendukung dan factor yang menghambat dalam penerapan pendidikan karakter dalam pembelajaran di Sekolah Dasar Negeri Dombo 1 Kecamatan Sayung Kabupaten Demak.

Peneliti sebagai Kepala Sekolah di Sekolah Dasar Negeri Dombo 1, melakukan perencanaan, pelaksanaan, pengumpulan data, analisis, penafsir data, dan menyusun pelaporan hasil penelitiannya. Pada penelitian ini instrumen utama adalah peneliti. Peneliti menjelajah ke seluruh bagian setting penelitian dengan mengumpulkan data secara cermat, tepat, dan benar sesuai fokus penelitian yakni penerapan pendidikan karakter dalam pembelajaran. Peneliti memilih responden untuk memberikan informasi data terhadap penelitian. Proses pemilihan informan peneliti menggunakan teknik purposive (bertujuan) yaitu peneliti memilih orangorang yang dianggap mengetahui secara jelas permasalahan yang akan diteliti. Peneliti menggunakan tiga tahapan dalam menentukan informan yaitu pemilihan informan awal, pemilihan informan lanjutan, dan menghentikan pemilihan informan lanjutan.Pada penelitian ini sumber data kualitatif, yaitu data yang disampaikan dengan deskripsi, sesuai dengan jawaban yang disampaikan subjek atau sumber penelitian berkaitan dengan seperangkat pertanyaan yang diajukan oleh peneliti. Data yang dikumpulkan dalam penelitian ini adalah data mengenai penerapan pendidikan kakrater dalam pembelajaran di Sekolah Dasar Negeri Dombo 1 Kecamatan Sayung Kabupaten demak Provinsi Jawa Tengah. Penelitian ini menggunakan dua sumber data, yaitu manusia dan bukan manusia. Sumber data manusia berfungsi sebagai subyek atau informasi kunci (key informants). Sedangkan sumber data bukan manusia yanga berupa dokumen yang sesuai atau relevan dengan fokus penelitian. Sumber data dalam penelitian ini adalah, kepala sekolah, guru-guru, tenaga kependidikan , komite Sekolah, peserta didik dan orang tua peserta didik, dokumen, maupun catatan hasil pengamatan.

Pemilihan sumber data untuk manusia sebagai informan dalam penelitian ini Sehubungan dengan wilayah sumber data yang dijadikan sebagai subyek penelitian ini ada dua, yaitu (1) Sumber data primer, yaitu sumber data yang diperoleh secara langsung dari lapangan, meliputi wawancara , kepada kepala sekolah, guru-guru,komite Sekolah, maupaun peserta didik, dokumen, dan catatan lapangan; (2) sumber data sekunder, yaitu catatan adanya peristiwa ataupun catatan-catatan yang jaraknya telah jauh dari sumber orisinil, antara lain orang tua/wali dari peserta didik sekolah tersebut. Sasaran penelitian yaitu, sebagian secara langsung didatangi untuk berwawancara dan berdialog, sebagian lainnya didatangi namun tidak diwawancarai dan tidak diajak dialog, namun hanya diamati dan diobservasi langsung dan tidak langsung. Jenis yang kedua ini sebagai konfirmasi informasi yang didapat dari jenis pertama. Hasil wawancara dan konfirmasi penerapan pengembangan kurikulum dikembangkan secara terbuka namun tetap memakai kendali yakni melalui triangulasi, pengecekan ulang informasi dari satu subyek pada subyek yang lain, sampai pada satu keadaan 'jenuh' yakni tanpa bantahan. Dengan demikian walau sumber informasi jumlahnya terbatas dan sifatnya purporsif, namun dengan proses pemeriksaan silang, triangulasi, dan pensiklusan kembali, peneliti tetap menuju pada kesatuan arti penerapam pendidikan karakter dalam pembelajaran. Data yang terkumpul dianalisis secara deksriptif dengan alur reduksi data, penyajian data, dan penarikan kesimpulan.

\section{HASIL DAN PEMBAHASAN}

Berdasarkan pemantauan Peneliti selama persiapan, pelaksanaan, dan tindak lanjut penelitian Study Kasus ini diperoleh berbagai data baik dari guru yang sedang melaksanakan proses belajar mengajar, tenaga kependidikanpeserta didik yang belajar,. Gambaran yang merupakan hasil dan temuan penelitian sebagai berikut antara lain melaksanakan kurikulum pendidikan umum dengan pendidikan karakter ini memiliki sebuah cita-cita yang mulia yaitu membentuk generasi mapan sehingga dalam kehidupannya dan menjadikannya sebagai bekal 
dalam meraih kesuksesan dengan prestasi yang gemilang. Berbagai kegiatan yang telah dilakukan dan prestasi telah diukir sehingga membantu mendorong perkembangan Sekolah Dasar Dombo 1 Kecamatan Sayung Kabupaten Demak menjadi salah satu Sekolah yang lebih maju. Sehingg animo masyarakat untuk menyekolahkan anaknya di sekolah ini dari tahun ke tahun selalu meningkat.

Kepala Sekolah Dasar negeri Dombo 1 telah membuat Tim Pengembang Kurikulum untuk menyusun pengembangan dokumen kurikulum Tingkat Satuan Pendidikan yang mengandung nilai-nilai karakter, setelah itu penyempurnaan dilakukan terhadap dokumen I dan II. Penyempurnaan terhadap dokumen I dilakukan dengan mengintegrasikan nilai-nilai pendidikan karakter ke dalam rumusan visi, misi, dan tujuan sekolah. Untuk dokumen II dengan mencantumkan nilai-nilai karakter di dalam silabus dan rencana pelaksanaan pembelajaran (RPP). Hal ini bisa dilihat dari visi, misi, dan tujuan yang ditetapkan oleh Sekolah Dasar Negeri Dombo 1 Kecamatan Sayung Kabupaten Demak yaitu : Visinya antara lain Mewujudkan Sistem Pendidikan Dasar Yang Mampu Menghasilkan Kompetensi Peserta Didik Atas Dasar Keteladanan, Kecerdasan, Kreativitas, Keunggulan, Beriman Dan Berbudi Pekerti Luhur sedangkan Misinya adalah: Menumbuhkan penghayatan terhadap ajaran agama dan budaya bangsa, sehingga menjadi sumber kearifan dalam perilaku sehari - hari Menjadikan kemajuan dan keberhasilan peserta didik dalam pendidikan sebagai pusat orientasi dan tujuan dalam semua kegiatan sekolah Mengembangkan profesionalitas guru sebagai pengembang dan pelaksana kurikulum sesuai dengan perkembangan iptek dan tuntutan kebutuhan masyarakat Membentuk dasar kompetensi peserta didik yang mantap baik iman dan taqwa maupun iptek sebagai bekal hidup di masyarakat dan untuk melanjutkan pendidikan ke jenjang yang lebih tinggi Mengembangkan seni budaya, dan olahraga sebagai sarana untuk membentuk pribadi luhur menumbuhkan siswa untuk peduli terhadap lingkungan, mencegah kerusakan dan menghindari pencemaran Sedangkan Tujuan Sekolah Dasar Dombo 1 antara lain Peserta didik beriman dan bertaqwa kepada Tuhan Yang Maha Esa dan berakhlak mulia. Peserta didik sehat jasmani dan rohani. Peserta didik memiliki dasar-dasar pengetahuan, kemampuan dan keterampilan untuk melanjutkan pendidikan pada jenjang yang lebih tinggi. Mengenal dan mencintai bangsa, masyarakat dan kebudayaannya.Siswa kreatif, terampil, dan bekerja untuk dapat mengembangkan diri secara terus menerus. Mencapai kelulusan 100\% dengan nilai ratarata Nilai 6,5 dan meningkat lulusannya diterima di sekolah negeri. Terwujudnya suasanan belajar yang bergairah dan menyenangkan. Menjuarai bidang olah raga di tingkat kabupaten.Meraih juara bidang akademik (LCC, OSN, siswa berprestasi) tingkat kabupaten.Meraih juara bidang mapsi tingkat Kabupaten Mewujudkan lingkungan sekolah yang aman, nyaman, dan menyenangkan. Sekolah juga berupaya mengoptimalkan peran serta orangtua dan masyarakat dalam proses pengelolaan sekolah dan pembelajaran. Untuk mendukung kebijakan ini, maka Sekolah Dasar Negeri Dombo 1 Kecamatan Sayung Kabupaten Demak menata lingkungan sekolah yang kondusif untuk penanaman nilai karakter dan membuat program-program sekolah yang eksplisit mengarah pada penanaman nilai-nilai karakter.

Pendidikan Karakter dalam Kegiatan Ekstrakurikuler Kegiatan ekstrakurikuler adalah kegiatan yang diselenggarakan di luar pelajaran wajib dengan tujuan untuk memperdalam dan memperluas pengetahuan peserta didik yang berhubungan dengan materi ekstrakurikuler yang dipilih. Melalui kegiatan ekstrakurikuler diharapkan peserta didik bisa mengembangkan bakat, minat, kepribadian, dan kemampuannya di berbagai bidang non akademik. Adapun kegiatan ekstrakurikuler yang menunjang pengembangan diri yang dilaksanakan di Sekolah Dasar Negeri Dombo 1 Kecamatan Sayung Kabupaten Demak,antara lain : 1. Pramuka; 2. sepek bola; 3. sepak Takrow; 4. bulutangkis; 5. Voly bal; 6. Mocopat; 7. baca puisi; 8. khifdil Qur;an; 9.Khitobah;10.Mocopat Islami; 11. komputer; Kegiatan ekstrakurikuler yang ada di Sekolah Dasar Negeri Dombo 1 Kecamatan Sayung Kabupaten Demak, dapat dikelompokkan ke dalam seni, olahraga, dan ilmiah. Pengelompokkan ini bertujuan agar segala potensi diri peserta didik dapat tertampung semua. Bakat, kemampuan, dan minat peserta didik berbeda-beda karena itu 
peserta didik diberi kebebasan untuk memilih salah satu ekstrakurikuler tersebut dan boleh memilih ekstrakurikuler lain. Kegiatan ekstrakurikuler ini ada yang bersifat ekstrakurikuler wajib dan ada ekstrakurikuler yang bersifat pilihan. Kegiatan ekstrakurikuler yang wajib diikuti oleh semua peserta didik adalah ekstra kurikuler Pramuka. Ekstrakurikuler pilihan antara lain: sepek bola; sepak Takrow; bulutangkis; Voly bal; Mocopat; baca puisi; khifdil Qur;an; Khitobah; Mocopat Islami; komputer, Secara umum, bidang ekstrakurikuler yang dikembangkan Sekolah Dasar Negeri Dombo 1 Kecamatan Sayung Kabupaten Demak dibagi dalam beberapa bidang sebagaimana diuraikan dalam tabel 1 .

Tabel 1. Data Kegiatan Ekstrakurikuler Sekolah Dasar Negeri Dombo 1 Kecamatan Sayung Kabupaten Demak

\begin{tabular}{|c|c|c|c|}
\hline No & $\begin{array}{l}\text { Kegiatan } \\
\text { Ekstrakurikuler }\end{array}$ & $\begin{array}{l}\text { Sub } \\
\text { Kegiatan } \\
\text { Ekstrakurikuler }\end{array}$ & $\begin{array}{l}\text { Karakter Positif yang Dibentuk dan } \\
\text { Diperkuat }\end{array}$ \\
\hline 1 & $\begin{array}{l}\text { Bidang } \\
\text { Kepramukaan }\end{array}$ & Pramuka & $\begin{array}{l}\text { Disiplin, keikhlasan, kerja keras, } \\
\text { ketaatan, berjuang dengan sungguh- } \\
\text { sungguh, jujur, berani, bertanggung } \\
\text { jawab, pengorbanan, kreatif, } \\
\text { komitmen, semangat kebangsaan, } \\
\text { konsisten, cinta damai, persaudaraan, } \\
\text { demokratis, toleransi, kepercayaan, } \\
\text { peduli sosial, mandiri, , peduli } \\
\text { lingkungan, rasa ingin tahu, dan } \\
\text { bersahabat }\end{array}$ \\
\hline 2 & Bidang Olahraga & $\begin{array}{l}\text { sepek bol; } \\
\text { sepakTakrow; } \\
\text { bulutangkis; Voly } \\
\text { bal }\end{array}$ & $\begin{array}{l}\text { Kreatif, mandiri, toleransi, kerja keras, } \\
\text { rasa } \\
\text { ingin tahu, bertanggung jawab, jujur, } \\
\text { disiplin, memperhalus rasa, cinta tanah } \\
\text { air, menghargai prestasi, dan gemar } \\
\text { membaca Disiplin, cinta damai, jiwa } \\
\text { fair play, kerja keras, toleransi, } \\
\text { bertanggung jawab, mandiri, } \\
\text { bersahabat, demokratis, percaya diri, } \\
\text { menghargai prestasi, kompetitif, } \\
\text { religius, kreatif, kerjasama, jujur, dan } \\
\text { semangat kebangsaan }\end{array}$ \\
\hline 3 & Bidang Seni Budaya & $\begin{array}{l}\text {; Mocopat; baca } \\
\text { puisi }\end{array}$ & $\begin{array}{l}\text { Kreatif, mandiri, toleransi, kerja keras, } \\
\text { rasa ingin tah } \\
\text { ingin tahu, bertanggung jawab, jujur, } \\
\text { disiplin, memperhalus rasa, cinta tanah } \\
\text { air, menghargai prestasi, dan gemar } \\
\text { membaca Disiplin, cinta damai, jiwa } \\
\text { fair play, kerja keras, toleransi, } \\
\text { bertanggung jawab, mandiri, } \\
\text { bersahabat, demokratis, percaya diri, } \\
\text { menghargai prestasi, kompetitif, } \\
\text { religius, kreatif, kerjasama, jujur, dan } \\
\text { semangat kebangsaan }\end{array}$ \\
\hline
\end{tabular}




\begin{tabular}{|l|l|l|l|}
\hline 4 & Bidang Keagamaan & $\begin{array}{l}\text { khifdil Qur;an; } \\
\text { Khitobah; Mocopat } \\
\text { Islami }\end{array}$ & $\begin{array}{l}\text { Religius, bertanggung jawab, gemar } \\
\text { membaca, kreatif, menghargai prestasi, } \\
\text { mandiri, cinta damai, bersahabat, dan } \\
\text { kerja keras }\end{array}$ \\
\hline 5 & Bidang Akademik & Komputer & $\begin{array}{l}\text { Berfikir kritis, rasa ingin tahu, kreatif, } \\
\text { sistematis, bersahabat/ komunikatif } \\
\text { peduli lingkungan, kerja keras, gemar } \\
\text { membaca, menghargai prestasi, } \\
\text { disiplin, dan peduli sosial }\end{array}$ \\
\hline
\end{tabular}

(Sumber: Dokumen Kegiatan Ekstrakurikuler Sekolah Dasar Negeri Dombo 1 Kecamatan Sayung Kabupaten Demak)

Pendidikan Karakter dalam Kegiatan Pembiasaan merupakan satu ciri dari Sekolah Dasar Negeri Dombo 1 Kecamatan Sayung Kabupaten Demak yang merupakan salah satu u saha untuk menanamkan karakter yang positif pada siswa sesuai dengan nilai-nilai religi. Kegiatan pembiasaan juga merupakan proses untuk pembentukan akhlak dan penanaman atau pengamalan ajaran agama Islam. Sekolah Dasar negeri Dombo 1 mempunyai program pembiasaan yang dibedakan menjadi pembiasaan rutin, pembiasaan terprogram, pembiasaan keteladanan, pekan kreativitas siswa, keunggulan lokal, dan keunggulan global. Pembiasaan rutin adalah kegiatan yang dilakukan secara regular di sekolah tersebut yang bertujuan untuk membisakan peserta didik untuk mengerjakan sesuatu dengan baik. Pembiasaan rutin yang dilakukan di Sekolah Dasar Negeri Dombo 1 Kecamatan sayung Kabupaten Demak di antaranya upacara Senin pagi, pemeriksaan kesehatan, senam pagi, membaca buku di perpustakaan pada saat istirahat, sholat berjamaah, $5 \mathrm{~S}$ (Senyum, Salam, Sapa, Sopan, Santun). Pembiasaan terprogram adalah kegiatan yang diprogramkan dan direncanakan baik pada tingkat kelas maupun sekolah. Bertujuan untuk memberikan wawasan tambahan pada peserta didik tentang unsur-unsur baru dalam kehidupan bermasyarakat yang sangat perlu dan penting untuk perkembangan peserta didik itu sendiri. Contoh kegiatan terprogram yang dilaksanakan di di Sekolah Dasar Negeri Dombo 1 Kecamatan Sayung Kabupaten Demak diantaranya kegiatan lomba-lomba antar sekolah (Lomba, FLS2N, O2SN, OSN, MAPSI ,POPDA, Gala Desa Persami, tempat-tempat penting atau bersejarah, bakti sosial, jambore).

Kegiatan keteladanan, bentuk kegiatannya berupa pembinaan kedisiplinan, kehadiran, pakaian, perlengkapan, dan kedisiplinan menjalankan tugas, penanaman akhlak islami, budaya bersih diri (periksa kuku, rambut,gigi dan telinga), dan penanaman budaya bersih lingkungan kelas maupun sekolah (lomba K3 antar kelas, kerja bakti di lingkungan sekolah ). Pembiasaan keteladanan ini merupakan kegiatan yang dapat dilakukan kapan saja, di mana saja yang lebih mengutamakan pemberian contoh dari guru maupun tenaga kependidikan yang lain kepada peserta didiknya. Bertujuan memberikan contoh atau teladan tentang kebiasaan yang baik dalam penanaman akhlak Islami. Berbagai macam poster terpasang di sekolah untuk menanamkan sikap pembiasaan keteladanan ini. Setiap ruangan kelas di sekolah tersebut, baik di dalam maupun di luar kelas dihiasi dengan kata-kata mutiara, semboyan, ayat Al-Qur;an, hadis, dan karya-karya peserta didik.

Untuk menciptakan kondisi kelas dan sekolah yang nyaman tidak membosankan peserta didik untuk belajar lebih nyaman dan menyenangkan, maka ruangan kelas selain ditata secara rapi dan bersih, keindahan juga menjadi hal penting. Di samping dengan pemajangan kata kata bijak atau pun kata-kata mutiara, juga dihiasi dengan gambar-gambar yang berkaitan dengan pelajaran, gambar, dan benda- benda hasil karyapeserta didik, serta hal-hal yang menarik sesuai dengan usia peserta didik. Pemajangan hasil karya peserta didik akan memberikan pengaruh yang posistif bagi peserta didik, karena mereka akan merasa dihargai kemampuannya, memotivasi peserta didik untuk selalu berkarya, mendorong kreativitas, tekun, 
serta teliti, rasa ingin tahu, jujur, dan kerja keras serta melatih kemandirian.

Dalam rangka memberi ruang bagi peserta didik untuk mengekspresikan diri maka di Sekolah Dasar Negeri Dombo 1 Kecamatan Sayung Kabupaten Demak mengadakan program pekan kreativitas peserta didik dalam bentuk lomba kreatifitas seni dan mencari bakat. Kegiatan ini bertujuan untuk meningkatkan kreativitas peserta didik dan sebagai sarana untuk mengaktualisasikan diri bagi peserta didik sesuai dengan kemampuan masing-masing. kegiatan ini biasanya dilakukan bertepatan dengan peringatan hari-hari besar Nasional maupun keagamaan. Sekolah Dasar Negeri Dombo 1 Kecamatan Sayung Kabupaten Demak mempunyai keunggulan lokal berupa bidang akademik yang terfokus tiga unggulan mata pelajaran yaitu matematika, Agama (MAPSI), dan Seni Budaya (Seni Suara) dibidang Olah raga yaitu Cabang Sepak bola, Volly bal dan Sepak Takraw Dengan keunggulan tersebut diharapkan peserta didik dapat memperoleh kejuaraan disetiap kancah lomba baik di tingkat kecamatan maupun tingkat kabupatenr serta memahami dan mempunyai kompetensi keunggulan tersebut untuk bekal dalam kehidupan dimasa yang akan datang. Berdasarkan hal tersebut dapat ditarik kesimpulan bahwa Sekolah Dasar Negeri Dombo 1 Kecamatan Sayung Kabupaten Demak mempunyai keunggulan lokal yang aplikatif dalam kehidupan sehari-hari, sehingga diharapkan peserta didik mimilki karakter yang baik dan kuat. Mempunyai karakter yang sesuai dengan harapan, dan bisa bermanfaat bagi orang lain pada umumnya. Selain Selain mempunyai program unggulan lokal juga memiliki program unggulan global, keunggulan global bentuk kegiatannya adalah pembelajaran komputer dengan harapan agar anak cakap menggunakan komputer dan akses internet apalagi mulai tahun 2021 sudah diberlakukan Assesnen Nasional Berbasis Komputer (ANBK). Di sekolah juga dilengkapi dengan koneksi internet melalui speedy dari telkom, fasilitas ini diperuntukkan untuk mendukung kegiatan pembelajaran bagi guru dan peserta didik. Bagi guru bisa menjadi media dalam menggali informasi yang dibutuhkan untuk proses Kegiatan Belajar Mengajar dan pengembangan kependidikan. Pelaksanaannya baik keunggulan lokal dan keunggulan global diintegrasikan ke dalam mata pelajaran muatan lokal dan diberikan sejak kelas I sampai dengan kelas VI. Unggulan lokal terkait dengan pembentukan karakter, dan unggulan global memberi bekal dalam menghadapi tantangan teknologi

Faktor Pendukung dan Penghambat Penerapan Pendidikan Karakter dalam Pembelajaran Beberapa faktor pendukung dalam penerapan pendidikan karakter dalam pembelajaran di Sekolah Dasar Negeri Dombo 1 Kecamatan Sayung Kabupaten Demak antara lain peserta didik yang aktifyang berjumlah 300 peserta didik, guru-guru yang tergolong masih muda, dan adanya dukungan dari sekolah untuk mengembangkan berbagai media yang dibuat oleh guru. Kepala sekolah dan pendidik serta tenaga kependidikan merupakan faktor yang mendukung penerapan Pendidikan karakter daalam pembelajaran sehingga perlu penyediaan sarana prasarana, seperti media pembelajaran. Media pembelajaran sangat diperlukan guru agar dapat menunjang tercapainya tujuan pendidikan sehingga guru tidak terlalu banyak mengeluarkan tenaga dalam penyampaian materi atau bahan pelajaran yang akan disampaikan. Selain faktor pendukung di atas faktor guru sangat menentukan dalam keberhasilan implementasi pembelajaran di kelas. Guru-guru mempunyai kemampuan yang dapat menunjang keberhasilan dalam melaksanakan kegiatan belajar mengajar sehingga sebelum melaksanakan proses pembelajaran guru mampu mengatur peserta didik dengan baik, mengembangkan metode mengajar yang diterapkan, menyiapkan dan membuat media belajar, mengadakan evaluasi dan membimbing peserta didiknya dengan baik. Selain faktor pendukung dalam implementasi pendidikan karakter dalam pembelajaran terdapat juga faktor penghambat atau kendala yang dihadapi guru di lapangan. Faktor penghambat tersebut diantaranya baik guru dan peserta didik merasa kecapean dan kelelahan dalam melaksanakan kegiatan belajar mengajar. Sebab jam pembelajaran yang panjang dari pagi hingga sore tentunya menguras tenaga dan pikiran. Faktor penghambat selanjutnya adalah dalam hal perbedaan kompetensi dari setiap peserta didik. Guru juga mengalami kesulitan dalam mengkondisikan peserta didik dalam belajar. Berdasarkan hal tersebut merupakan tantangan bagi guru untuk bisa memahami 
karakteristik peserta didik setiap individunya. Guru harus memahami perbedaan peserta didk satu dengan yang lain agar dapat mengkondisikan dalam belajar dan melakukan pengelolaan pembelajaran dengan baik.

\section{Pembahasan}

Berdasarkan hasil temuan pada saat observasi pembelajaran di kelas dapat terlihat bahwa guru menggunakan tempat belajar, media, dan metode yang variatif serta aplikatif. Guru diberi kebebasan mengelola pembelajaran seefektif dan seefisien mungkin agar tercapai tujuan pembelajaran secara optimal dan tercipta pembelajaran yang menyenangkan dan melibatkan partisipasi peserta didik. Sehingga berdasarkan temuan kasus di Sekolah Dasar Negeri Dombo 1 Kecamatan Sayung Kabupaten Demak, maka sejalan dengan Peraturan Pemerintah Republik Indonesia Nomor 32 Tahun 2013 Tentang Perubahan Atas Peraturan Pemerintah Nomor 19 Tahun 2005 Tentang Standar Nasional Pendidikan Pasal 19 ayat

"Proses pembelajaran pada satuan pendidikan diselenggarakan secara interaktif, inspiratif, menyenangkan, menantang, memotivasi peserta didik untuk berpartisipasi aktif, serta memberikan ruang yang cukup bagi prakarsa, kreativitas, dan kemandirian sesuai dengan bakat, minat, dan perkembangan fisik serta psikologis peserta didik. Guru-guru di Sekolah Dasar Negeri Dombo 1 Kecamatan Sayung Kabupaten Demak sebelum melakukan kegiatan pembelajaran telah menyiapkan RPP (Rencana Pelaksanaan Pembelajaran), media pembelajaran, metode mengajar, sumber belajar, dan evaluasi pembelajaran. Dengan menyiapkan persiapan pembelajaran yang matang maka separo keberhasilan dalam suatu proses pembelajaran sudah bisa tercapai dan setengahnya lagi terletak pada pelaksanaan pembelajaran. Sebagaimana dengan pendapat Hakiim (2009) bahwa perencanaan dan pelaksanaan pembelajaran belum tentu akan mencapai keberhasilan guru dalam pembelajaran jika dilakukan sembarangan sehingga proses pembelajaran menjadi kurang menarik, membosankan, tidak merangsang peserta didik untuk aktif dan berpikir kreatif sehingga merasa jenuh yang berakibat tujuan pembelajaran tidak bisa tercapai dengan maksimal.. Oleh sebab itu, perencanaan yang baik dan pelaksanaan yang tepat akan menentukan keberhasilan proses pembelajaran.Berdasarkan hasil temuan selanjutnya pada saat observasi pembelajaran di kelas, guru dalam mengajar konsep materi pembelajaran disampaikan dengan mempertimbangkan kedalaman dan keleluasaan materi, sikap mental yang dikembangkan, internalisasi nilai-nilai keagamaan, kesesuaian kontekstual, dan informasi kekinian. Sependapat dengan Hakiim (2009) bahwa "Standar materi berisikan jenis, kedalaman, dan ruang lingkup materi pembelajaran yang harus dikuasai peserta didik, sedangkan standar penampilan berisikan tingkat penguasaan yang harus ditampilkan peserta didik". Secara garis besar, materi pembelajaran berisikan pengetahuan, keterampilan, dan sikap atau nilai yang harus dipelajari peserta didik yang bersangkutan. Berkaitan dengan hasil temuan dalam observasi di Sekolah Dasar Negeri Dombo 1 Kecamatan Sayung Kabupaten Demak mengenai pembinaan peserta didik, pada prinsipnya pembinaan peserta didik tersebut diarahkan dalam rangka terbentuknya pribadi yang berkarakter, meningkatkan peran serta, dan inisiatif para pesrta didik untuk menjaga dan membina diri serta lingkungannya sehingga terhindar dari usaha dan pengaruh budaya yang bertentangan dengan nilai-nilai kebangsaan. Strategi pembinaan peserta didik yang dilaksanakan di Sekolah Dasar Negeri Dombo 1 Kecamatan Sayung Kabupaten Demak yang berkaitan dengan penanaman dan pembiasaan-pembiasaan dalam rangka penanaman karakter melalui pengembangan diri yang terdiri dari ekstrakurikuler dan pembiasaan. Pengembangan diri di Sekolah Dasar Negeri Dombo 1 Kecamatan Sayung Kabupaten Demak, meliputi kegiatan ekstrakurikuler, kegiatan pembiasaan, kegiatan keteladanan, kegiatan nasionalisme dan patriotisme, pembelajaran luar sekolah, pekan kreativitas peserta didik, dan keunggulan local maupun global. Pengembangan diri ini merupakan pembiasaan yang bertujuan untuk menanamkan pembiasaan-pembiasaan yang baik pada peserta didik, pembiasaan yang baik dan dilakukan secara terus menerus akan menjadi karakter pada diripeserta didik. Pengembangan diri ini sebagai sarana untuk pembiasaan, penanaman, dan sekaligus pemantauan dalam 
penanaman karakter sesuai dengan nilai-nilai kebangsaan yang secara pemahaman atau teori sudah diajarkan dalam mata pelajaran yang ada. Berkaitan dengan pembiasaan keteladanan, hal ini sesuai dengan pendapat Wiyani (2012) yang menyatakan bahwa pembiasaan keteladanan adalah kegiatan dalam bentuk perilaku sehari-hari yang tidak diprogramkan karena dilakukan tanpa mengenal batasan ruang dan waktu. Keteladanan ini merupakan perilaku dan sikap guru dan tenaga kependidikan dan peserta didik dalam memberikan contoh tindakan-tindakan yang baik sehingga diharapkan bisa menjadi panutan bagi peserta didik yang lainnya. Pembiasaan keteladanan di sekolah ternyata mampu mengantarkan peserta didik untuk berbuat yang sesuai dengan etika.

Dampak pembiasaan keteladanan dalam suatu organisasi terlihat dalam Tabel 2.

Tabel 2. Dampak Perilaku Keteladanan dalam Organisasi

\begin{tabular}{|l|l|l|}
\hline No & Perilaku & \multicolumn{1}{c|}{$\begin{array}{c}\text { Dampak Perilaku Keteladanan dalam } \\
\text { Organisasi }\end{array}$} \\
\hline 1. & Fikiran & $\begin{array}{l}\text { Perta didik mulai belajar berpikir positif (positif } \\
\text { thinking). Hal ini dapat dari perilaku mereka untuk } \\
\text { selalu mau mengakui kesalahan sendiri dan mau } \\
\text { memanfaatkan orang lain. Peserta didik juga mulai } \\
\text { menghilangkan prasangka buruk terhadap orang } \\
\text { lain. Mereka selalu terbuka dan mau bekerja sama } \\
\text { dengan siapa saja tanpa memandang perbedaan } \\
\text { agama, suku, dan ras }\end{array}$ \\
\hline 2 & Perkataan & $\begin{array}{l}\text { Perilaku yang sesuai dengan etika ialah tutur kata } \\
\text { peserta didik yang sopan, misalnya mengucapkan } \\
\text { salam kepada guru atau tamu yang datang, } \\
\text { mengucapkan terima kasih jika diberi sesuatu, } \\
\text { meminta maaf jika melakukan kesalahan, dan } \\
\text { berkata jujur. Hal sekecil ini jika dibiasakan sejak } \\
\text { kecil akan menumbuhkan sikap positif. Sikap } \\
\text { tersebut, misalnya menghargai pendapat orang lain } \\
\text { dan jujur dalam bertutur kata dan bertingkah laku }\end{array}$ \\
\hline 3 & $\begin{array}{l}\text { Tingkah laku yang terbentuk dari perilaku religius } \\
\text { tentunya tingkah laku yang benar, yang sesuai } \\
\text { dengan etika. Tingkah laku tersebut di antaranya } \\
\text { empati, hormat, kasih sayang, dan kebersamaan }\end{array}$ \\
\hline
\end{tabular}

Apabila di suatu sekolah yang terdiri atas kepala sekolah, guru-guru, tenaga kependidikan, dan para siswa apabila terbiasa hidup dalam lingkungan kebiasaan keteladanan, kebiasaan-kebiasaan, maka akan melekat dalam dirinya dan diterapkan di mana pun mereka berada. Begitu juga sikapnya dalam berucap, berpikir, dan bertingkah laku akan didasarkan norma agama, moral, dan etika yang berlaku. Jika hal ini diterapkan di semua sekolah khususnya bagi para pendidik (guru), maka akan terbentuk generasi- generasi muda yang handal, bermoral, dan beretika (berakhlakul karimah) (Rustiningsih dalam Kompri, 2015). Maka dari itu, kepala sekolah selaku Pimpinan atau manajer harus lebih mengedepankan aspek religius yang harus ditanamkan di lembaga yang dikelolanya, terutama bagi para guru (pendidik) bidang umum dan agama karena guru berhadapan langsung dengan peserta didik. Koordinasi yang baik antara kepala sekolah dengan warga sekolah membuat pelaksaanaan Pendidikan di Sekolah Dasar Negeri Dombo 1 Kecamatan Sayung Kabupaten Demak dengan baik dan nilai- nilai karkater tersebut tidak hanya diterapkan untuk para peserta didiknya, tetapi juga kepada guru, karena dari gurulah peserta didik akan mengimitasi atau meneladaninya dalam kehidupan sehari hari. 
Faktor-faktor pendukung dalam penerapan pendidikan karakter dalam pembelajaran diantaranya peserta didik yang aktif dalam setiap pembelajaran yang dilaksanakan didalam kelas maupun di luar kelas. Menurut Suryadi (2009) pembelajaran yang baik adalah pembelajaran yang menuntut keaktifan peserta didik. Melalui proses pembelajaran dengan keterlibatan aktif peserta didik ini berimplikasi terhadap peserta didik itu sendiri untuk membangun pengetahuannya sehingga mereka akan memperoleh pemahaman yang mendalam dan akhirnya meningkatkan kompetensi peserta didik tersebut. Hal ini sejalan dengan pendapat Kosasih (2014) bahwa "pembelajaran yang bermakna dapat dibangun dengan memerhatikan struktur kognitif peserta didik sehingga akan terkesan begitu lama dalam ingatan/memori nya (terjadi rekonstruksi)". Dalam pencapaian tujuan pembelajaran untuk mengarah suatu efektivitas pembelajaran diperlukan desain pembelaran. Desain pembelajaran itu akan mempermudah peserta didik dalam mengikuti pembelajaran yang telah dirancang oleh guru atau pendidik. Persiapan pembelajaran yang matang akan menghasilkan suatu aktifitas belajar mengajar yang benar-benar tertata secara sistematik. Sependapat dengan hal tersebut Suryadi (2009) menyatakan bahwa "desain pembelajaran merupakan keseluruhan proses menganalisis kebutuhan pembelajaran, menetapkan tujuan pembelajaran, mengembangkan metode atau strategi pembelajaran yang optimal untuk mencapai tujuan hasil pembelajaran yang diinginkan dan menetapkan serta memilih materi pembelajaran". Berkaitan dengan administrasi pembuatan Rencana Pelaksanaan Pembelajaran, silabus, target-target pembelajaran, evaluasi atau penilaian yang digunakan, guru-guru di Sekolah Dasar Negeri Dombo 1 Kecamatan Sayung Kabupaten Demak telah melaksanakan dengan sangat baik. Kepemimpinan kepala sekolah yang selalu melakukan supervisi, baik dalam bentuk briefing, sharing, kunjungan ke kelas, atau motivasi kepada guru untuk memberikan jalan keluar atau solusi jika ditemukan kendala atau hambatan dalam proses belajar mengajar di kelas merupakan faktor pendukung dalam implementasi pembelajaran di kelas. Kegiatan supervisi yang dilakukan oleh kepala sekolah tersebut sejalan dengan pendapat Mulyasa (2012) bahwa hakikat supervisi adalah pembinaan yang berkelanjutan, pengembangan kemampuan profesional, perbaikan situasi belajar mengajar, dengan tujuan akhir pencapaian tujuan pendidikan dan pertumbuhan pribadi peserta didik. Menurut Purwanto (1977: 87) supervisi adalah suatu aktivitas pembinaan yang diharapkan dapat meningkatkan kemampuan sekolah maupun guru. Oleh sebab itu, supervisor harus dilakukan oleh orang yang memiliki pengetahuan dan keterampilan mengadakan hubungan antarindividu dan keterampilan teknis. Supervisor di dalam tugasnya bukan saja mengandalkan pengalaman sebagai modal utama, tetapi harus diikuti dengan jenjang pendidikan formal yang memadai. Menurut Depdiknas (1884:2) supervisi tersebut harus dilaksanakan secara: (1) sistematis, maksudnya supervisi dikembangkan dengan perencanaan yang matang sesuai dengan sasaran yang diinginkan, (2) objektif, artinya supervisi memberikan masukan sesuai dengan aspek yang terdapat dalam instrumen, (3) Realistis artinya supervisi didasarkan atas kenyataan sebenarnya yaitu pada keadaan atau hal-hal yang sudah dipahami dan dilakukan oleh para staf sekolah, (4) antisipatif, artinya supervisi diarahkan untuk menghadapi kesulitan-kesulitan yang mungkin akan terjadi, (5) konstruktif, artinya supervisi memberikan saran-saran perbaikan kepada yang disupervisi untuk terus berkembang sesuai ketentuan atau aturan yang berlaku, (6) kreatif, artinya supervisi mengembangkan kreativitas dan inisiatif guru dalam mengembangkan proses belajar mengajar, (7) kooperatif, artinya supervisi mengembangkan perasaan kebersamaan untuk menciptakan dan mengembangkan situasi belajar mengajar yang lebih baik, (7) kekeluargaan, artinya supervisi mempertimbangkan saling asah, saling asuh, tut wuri handayani.

Selain daya dukung di atas, dalam penerapan pendidikan karakter dalam pembelajaran di SDIT Insan Sejahtera Kabupaten Sumedang juga terdapat beberapa kendala atau faktor penghambat. Faktor penghambat tersebut dian taranya faktor kelelahan yang dialami oleh beberapa guru dan peserta didik karena cukup lama berada di sekolah. Muatan kurikulum Sekolah Dasar Negeri Dombo 1 Kecamatan Sayung Kabupaten Demak cukup banyak, secara otomatis akannya berpengaruh pada waktu pelaksanaan proses belajar mengajar, dan hal ini 
mempengaruhi terhadap jam kepulangan peserta didik. Setelah pulang sekolah juga diselenggarakan beberapa kegiatan ekstrakurikuler yang dibimbing oleh seorang guru yang menjadi penanggungjawab kegiatan ekstrakurikuler tersebut. Walaupun untuk beberapa guru juga waktu pembelajaran yang cukup panjang ternyata bukan suatu kendala bagi siswa, orang tua, guru, serta yayasan. Siswa tetap semangat dalam kegiatan pembelajaran walaupun waktu atau jam pembelajarannya cukup lama hal ini disebabakan adanya faktor-faktor yang mendukung yaitu, kenyamanan suasana di sekolah dan di kelas, pembalajaran yang menyenangkan, dan interaksi antara murid dan guru yang baik, guru bisa menempatkan diri atau berfungsi seperti orang tua mereka sendiri, bahkan kadang guru memposisikan diri seperti teman dalam rangka menjalin keterbukaan dengan tetap memperhatikan batas-batasnya. Faktor sebagai penghambat berikutnya adalah perbedaan kompetensi setiap peserta didik yang berbeda-beda satu sama lain sehingga guru harus menyiapkan metode, media, pengelolaan kelas, dan evaluasi atau penilaian yang tepat sesuai dengan karakter peserta didik tersebut. Hal ini sejalan dengan pendapat Asrori (2008) bahwa guru harus mengetahui dan mendalami karakteristik yang ada di dalam diri peserta didiknya secara menyeluruh yang merupakan suatu kesatuan yang tak terpisahkan.

Pada saat observasi, peneliti melihat sarana dan prasarana pendidikan seperti ruang perpustakaan masih belum maksimal. Untuk itulah, kepala Sekolah selalu berupaya untuk melengkapi berbagai sarana prasarana pendidikan dengan menganggarkan dana Bantuan Operasional Sekolah untuk belanja modal guna melengkapai sarana dan prasarana yang belum dimiliki atau belum lengkap. Disamping itu kepala sekolah juga berusaha untuk mencari terobosan dengan mengajukan proposal ke Dinas Pendidikan maupun lewat bantuan aspirasi dewan untuk memiliki ruang-ruang laboratorium, ruang Usaha Kesehatan Sekolah (UKS), dan ruang guru dan ruang kepala sekolah untuk terpisah yang masih dalam satu ruangan. Selain dari pada itu Kepala Sekolah bekerjasama dengan Komite Sekolah dan orang tua peserta didik untuk berpartisipasi dalam program peninggian halaman dan pavingisasi halaman yang selalu kebanjiran serta mengadakan program amal jumat berkah untuk melanjutkan pembangunan mushola sekolah. Berkaitan dengan hal ini Mulyasa (2012) menerangkan bahwa "pelibatan orang tua dan masyarakat bertujuan untuk: (1) memajukan kualitas pembelajaran dan pertumbuhan siswa; (2) memperkokoh tujuan serta meningkatkan kualitas hidup dan penghidupan masyarakat; dan (3) menggairahkan masyarakat untuk menjalin hubungan dengan sekolah". Kepala sekolah merupakan kunci untuk dapat menciptakan hubungan yang harmonis antara sekolah dan masyarakat secara efektif. Kepala sekolah dituntut untuk selalu berusaha meningkatkan dan membina hubungan kerja sama yang baik antara sekolah dan masyarakat maupun pemerintah deesa agar mewujudkan sekolah yang efektif dan efisien. Hal ini juga sependapat dengan Suryadi (2009) bahwa "kepala sekolah adalah perencana, pelaksana, dan penentu kebijakan hampir semua bentuk kerja sama sekolah dengan masyarakat". Keberhasilan sekolah sangat bergantung pada keberhasilan kepala sekolah. Sekolah yang dikepalai oleh orang yang mempunyai komitmen tinggi terhadap peningkatan mutu maka sekolah tersebut akan cepat berkembang karena kunci keberhasilan sekolah sangat bergantung pada kepalanya. Menurut Pidarta (1980 : 205) dalam Pelangi (2005:23) kepala sekolah merupakan kunci kesuksesan sekolah dalam mengadakan perubahan. Sehingga kegiatan meningkatkan dan memperbaiki program dan proses pembelajaran di sekolah sebagian besar terletak pada diri kepala sekolah itu sendiri. Lebih lanjut Pidarta (1980: 207) menyatakan bahwa kepala sekolah memiliki peran dan tanggung jawab sebagai manajer pendidikan, pemimpin pendidikan, supervisor pendidikan, dan administrator pendidikan.

Dalam hal kinerja, kepala sekolah harus melaksanakan tugas utamanya menjadi kepala sekolah tersebut dengan penuh tanggung jawab. Menurut format penilaian kinerja sekolah, kepala sekolah harus melaksanakan tugasnya yang berkaitan dengan kepala sekolah sebagai pendidik (edukator), kepala sekolah sebagai manajer, kepala sekolah sebagai administrator, kepala sekolah sebagai penyelia (supervisor), kepala sekolah sebagai pemimpin (Leader), kepala sekolah sebagai enterprenaur (kewirausahaan). Kepala sekolah sebagai menajer di 
sekolah harus mampu merencanakan sesuatu atau mencari stategi yang terbaik, mengorganisasi dan mengkoordinasi sumber-sumber pendidikan yang masih berserakan agar menyatu, dan mengadakan kontrol terhadap pelaksanaan dan hasil pendidikan. Atas perannya sebagai manajer, kepala sekolah dituntut mampu: (1) mengadakan prediksi masa depan sekolah misalnya tentang kualitas masyarakat yang diinginkan masyarakat, (2) melakukan inovasi dengan mengambil inovatif dan kegiatan-kegiatan yang kreatif untuk kemajuan sekolah, (3) menciptakan strategi atau kebijakan untuk menyukseskan pikiran-pikiran yang inovatif tersebut, (4) menyusun perencanaan, baik perencanaan strategis maupun perencanaan operasional, (5) menemukan sumber-sumber pendidikan dan menyediakan fasilitas pendidikan,(6) melakukan pengendalian atau kontrol terhadap pelaksanaan pendidikan dan hasilnya di sekolah yang dipimpinnya.

\section{KESIMPULAN}

Penerapan Pendidikan karakter dalam pembelajaran dilaksanakan melalui proses internalisasi nilai-nilai relegius dan kebangsaan dengan nilai-nilai ilmu pengetahuan umum ke dalam proses pembelajaran di kelas dan kegiatan sekolah. Strategi pembinaan peserta didik yang dilaksanakan di Sekolah Dasar Negeri Dombo 1 Kecamatan Sayung Kabupaten Demak secara terintegrasi, terpadu, dan komprehensif, melalui (1) pengintergrasian ke dalam setiap mata pelajaran, yang bertujuan untuk memperkenalkan nilai-nilai pendidikan karakter di setiap mata pelajaran, (2) adanya program ko-kurikuler dan ekstrakurikuler sebagai sarana pengembangan diri dan kegiatan pembiasaan, (3) budaya sekolah, (4) melalui peran serta masyarakat yang semuanya bertumpu pada nilai-nilai religius. Hasil dari implementasi Pendidikan karakter di Sekolah Dasar Negeri Dombo 1 Kecamatan Sayung Kabupaten Demak dapat dilihat dari nilai-nilai yang berkembang di kelas dan di sekolah.

Implementasi pembelajaran sifatnya akademis lebih didominasi dalam proses pembelajaran oleh guru di dalam kelas dan implementasi yang bersifat non akaemis lebih banyak dilaksanakan oleh pihak sekolah yang didukung oleh eksistensi peran komite sekolah.

Kementerian Pendidikan dan Kebudayaan telah menetapkan nilai-nilai pendidikan karakter sebagai prioritas pengembangan Penguatan Pendidikan Karakter. Dan lima karakter utama yang turut menetukan pentingnya pendidikan karakter yaitu: 1.Religius yang diwujudkan dalam perilaku melaksanakan ajaran agama dan kepercayaan yang dianut, menghargai perbedaan agama dan kepercayaan lain. 2 Nasionalis yang ditunjukkan melalui apresiasi budaya bangsa sendiri, menjaga lingkungan, taat hukum, disiplin, menghormati keragaman budaya, suku, dan agama. 3 Integritas yang meliputi sikap tanggung jawab, konsistensi tindakan dan perkataan yang berdasarkan kebenaran, menghargai martabat individu, serta mampu menunjukkan keteladanan. 4 Mandiri yaitu menjadi pembelajar sepanjang hayat, mempergunakan segala tenaga, pikiran, waktu untuk merealisasikan harapan, mimpi, dan citacita . 5 Gotong royong yaitu diharapkan peserta didik menunjukkan sikap menghargai sesama, dapat bekerja sama, inklusif, tolong menolong, memiliki empati dan rasa solidaritas Sebelum proses pembelajaran berlangsung guru-guru di Sekolah Dasar Negeri Dombo 1 Kecamatan Sayung Kabupaten Demak telah menyiapkan Rencana Pelaksanaan Pembelajaran, media pembelajaran, metode mengajar, sumber belajar, dan evaluasi atau penilaian pembelajaran. Dengan perencanaan dan persiapan pembelajaran yang telah disiapkan secara matang sebelumnya maka tujuan pembelajaran akan tercapai dan merupakan kunci keberhasilan dari proses pembelajaran. Penerapan pembelajaran dilakukan dengan menggunakan pendekatan pembelajaran aktif, kreatif, efektif, dan menyenangkan. Guru diberi kebebasan mengelola pembelajaran seefisien dan seefektif mungkin agar tercapai tujuan pembelajaran secara optimal dan tercipta pembelajaran yang menyenangkan dan melibatkan partisipasi peserta didik.

Dalam penerapan pembelajaran untuk mengatasi berbagai kendala atau faktor penghambat tersebut kepala sekolah berusaha memberdayakan faktor-faktor pendukung yang telah dimiliki oleh sekolah tersebut. Berbagai upaya atau strategi yang ditempuh oleh kepala sekolah antara lain melakukan supervisi, baik dalam bentuk briefing, sharing, kunjungan ke 
kelas, atau motivasi kepada guru untuk memberikan solusi jika ditemukan kendala atau hambatan dalam proses pembelajaran di kelas merupakan faktor pendukung dalam implementasi pembelajaran di kelas.Dari aspek kelengkapan sarana prasarana kepala sekolah selalu berupaya untuk melengkapi berbagai sarana prasarana pendidikan melalui penganggaran belanja modal dari dana BOS dan kerja sama dengan orang tua peserta didik serta mengajukan permohonan bantuan kepada pemerintah maupun dana aspirasi Dewan Perwakiln Rakyat. Kepala Sekolah Sekolah Dasar Negeri Dombo 1 Kecamatan Sayung Kabupaten Demak juga berusaha untuk memaksimalkan potensi yang ada pada sekolah untuk mengelola dan mengembangkan sekolah dengan baik dengan cara bekerja sama dengan orang tua peserta didik untuk memajukan pendidikan pada sekolah tersebut.

\section{DAFTAR PUSTAKA}

Abady, Y. 2012. Konsepsi dan Praktis Politik Islam (Abdul Qahar Mudzakar). Jakarta: Rabbani Press.

Asrori, M. 2008. Psikologi Pembelajaran. Bandung : Wacana Prima.

Bogdan, R. C. \& Biklen, S. K. 1998. Qualitative Research for Education: An Intriduction to Theory and Method. London: Allyn and Bacon, Inc.

Depdiknas. 2005. Peraturan pemerintah Nomor 19 Tahun 2005 tentang Standar Nasional Pendidikan ,Jakarta

Hakiim, L. 2009. Perencanaan Pembelajaran. Bandung: Wacana Prima.

Kompri. 2015. Manajemen Pendidikan: Komponen- Komponen Elementer Kemajuan Sekolah. Yogyakarta: Ar-Ruzz Media.

Mulyasa, E. 2012. Manajemen dan Kepemimpinan Kepala Sekolah. Jakarta: Bumi Aksara.

Peraturan Pemerintah Republik Indonesia No. 32 Tahun 2013 Tentang Perubahan Atas Peraturan Pemerintah Nomor 19 Tahun 2005 Tentang Standar Nasional Pendidikan.

Pidarta, I Made. 1980. Perencana Pendidikan Dengan Pendekatan Sistim. Jakarta: Rineke Cipta.

Purwanto, Ngalim. 1988. Administrasi dan Supervisi Pendidikan. Bandung: Remaja Karya.

Suryadi. 2009. Manajemen Mutu Berbasis Sekolah (Konsep dan Aplikasi). Bandung: Sarana Panca Karya Nusa.

Undang-Undang Republik Indonesia Nomor 20 Tahun 2003 Tentang Sistem Pendidikan Nasional.

Wiyani, N.A. 2012. Manajemen Pendidikan Karakter: Konsep dan Implementasinya di Sekolah. Yogyakarta: Pustaka Insan Madan 